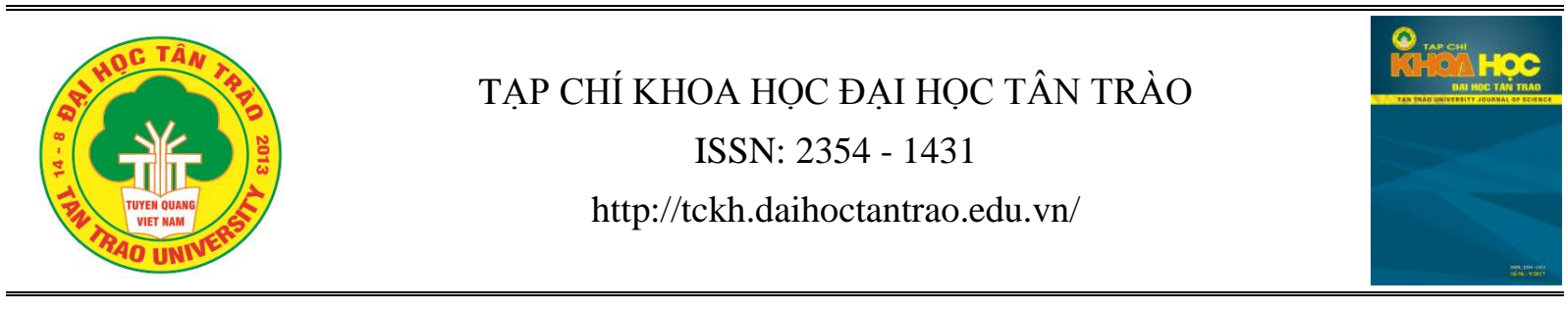

\title{
GETTING THROUGH THAT INVISIBLE WORD: LESSONS FROM STRUGGLING READERS
}

\author{
Donna G. Magallanes, ${ }^{1, *}$ \\ ${ }^{1}$ Faculty, College of Teacher Education and Technology, University of Southeastern Philippines, Philippines \\ Tagum-Mabini Campus \\ Tagum Unit \\ Tagum City, Davao del Norte \\ "Email address: d.magallanes@usep.edu.ph \\ https://doi.org/10.51453/2354-1431/2021/478
}

\section{Article info}

Recieved:

6/11/2020

Accepted:

22/02/2021

\section{Keywords:}

Invisible word, struggling reader, developing reader,

Sagayen National High

School

\begin{abstract}
:
The Sagayen National High School (SNHS) in Asuncion, Davao del Norte, has not been exempted from the enduring struggle caused by the perennial problem in reading. The result of the Philippine Informal Reading Inventory (PIRI) conducted to its Grade 7 students has provided a backdrop of the reality that besets our students in the secondary schools. The College of Teacher Education and Technology, through the Bachelor of Secondary Education (BSED) Department, answers the challenge via the "Summer Big Brother/Sister: Learning is Fun Project", a project in the Integrated Reading Enhancement Approach to Developing Readers (i-READR) Program: A Community Extension Program to a Participatory Action Research. This was designed to eventually transform frustration-level readers into "grade-level" readers, implemented in three years. Through Participatory Action Research (PAR), the Project provides for these identified "frustration-level" readers to develop the necessary skills not just to "make sense" of the written word but, more importantly, overcome the invisible yet more serious consequences of their condition. This is in consonance with PAR, which, according to McTaggart (1997), encourages capacity development and capacity building of all who participate. Findings reveal that struggling readers have more serious social problems that are caused by their inability to read. Enhancements in the existing reading program are also necessary to cater to the growing reading-related needs of the learners.
\end{abstract}


TẠP CHÍ KHOA HỌC ĐẠI HỌC TÂN TRÀO

ISSN: $2354-1431$

http://tckh.daihoctantrao.edu.vn/

\title{
CHINH PHỤC NHŨ்NG TÙ TRÙU TƯợNG: BÀI HỌC TỪ NHŨ̃NG NGƯờI ĐỌC NỖ LỰC
}

\author{
Donna G. Magallanes ${ }^{1, *}$ \\ ${ }^{I}$ Faculty, College of Teacher Education and Technology, University of Southeastern Philippines, Philippines \\ Tagum-Mabini Campus \\ Tagum Unit \\ Tagum City, Davao del Norte \\ *Email address:d.magallanes@usep.edu.ph \\ https://doi.org/10.51453/2354-1431/2021/478
}

\section{Thông tin bài viết}

Ngày nhận bài:

$6 / 11 / 2020$

Ngày duyệt đăng:

$22 / 02 / 2021$

\section{Tù̀ khóa:}

Tù̀ trùu tượng, người đọc nô lục, phát triển người đọc, Truòng trung học quốc gia Sagaven

\section{Tóm tắt}

Trường Trung học Quốc gia Cagayan (SNHS) ở Asuncion, Davao del Norte, đã có những cuộc tranh luận lâu dài về vấn đề kỹ năng đọc. Kết quả khảo sát các học sinh lớp 7 của tổ chức Đánh kỹ năng đọc thông thường của Philippines (PIRI) đã cho thấy một thực trạng đáng báo động đối với các học sinh bậc trung học cơ sở. Khoa Giáo dục trung học thuộc Trường Đại học Sư phạm và Công nghệ đã thực hiện dự án "Mùa hè anh em: Học tập là một dự án thú vị”dự án thuộc chương trình: Phương pháp tiếp cận nâng cao khả năng đọc tích hợp để phát triển người đọc- Từ cộng đồng đến nghiên cứu trường hợp có sự tham gia. Dự án được triển khai trong 3 năm với mục đích biến đổi người đọc từ cấp độ "thất bại” lên cấp độ "bậc trung". Bằng phương pháp Nghiên cứu có sự tham gia (PAR), Dự án đã giúp những người đọc ở cấp độ "thất bại” phát triển những kỹ năng cần thiết không chỉ để hiểu ngôn ngữ viết thông thường mà quan trọng hơn là hiểu được những từ trừu tượng. Kết quả nghiên cứu này cũng phù hợp với những phát hiện của Mc Taggart (1997) tại nghiên cứu về khuyến khích phát triển năng lực và nâng cao năng lực của tất cả những người tham gia. Kết quả chỉ ra rằng nguyên nhân khiến những người đọc mặc dù nỗ lực nhưng thất bại trong kỹ năng đọc của họ là do họ đang gặp phải nhiều vấn đề nghiêm trọng trong xã hội. Do đó, việc cải tiến trong chương trình đọc hiện tại là rất cần thiết để đáp ứng nhu cầu ngày càng tăng liên quan đến kỹ năng đọc hiểu của người đọc.

\section{Introduction}

The literature on reading has undeniably revealed the significance of reading as a life skill. As Lesturd (2013) points out, reading skills lead a person to interact and gain meaning from written language. Life, therefore, is meaningless if one does not know how to read as reading is making sense of the word. Making sense of the word, in turn, makes it possible for people to survive. More importantly, being able to "make sense of the word" ushers in a transformation within the person -something that is invisible to the eye.

Studies on reading comprehension and other reading micro skills have also been vast, having accumulated through the years. Most of these reading-performance researches have been designed to be experimental in nature. This study, although involving the before-and-after design has 
employed the Participatory Action Research (PAR). All stakeholders, therefore, play significant roles in the conduct of the study and in the implementation of the intervention, the reading remediation camp. Thus, this study potentially fills the methodological gap -as this study offers a different view using another method/research design, the participatory action research.

Project 3 or the "Summer Big Brother/Sister: Learning is Fun" is the third project of the lntegrated Reading Enhancement Approach to Developing Readers (I-READR) Program - ASP SAGAYEN: A Community Extension Program to a Participatory Action Research. This is a three-year extension program of the College of Teacher Education and Technology (CTET). Designed to combat illiteracy (and numeracy) among high school students of the Sagayen National High School(SNHS), the intervention is conducted through a culturally sensitive and relevant literacy (and numeracy) program.

\subsection{How it came into being and the challenges behind}

Summer Big Brother/Sister: Learning is Fun as a project specifically aims to improve the English reading skills of Grade 7 students in Sagayen National High School. Specifically, these were the students who were identified as frustration-level readers.

To realize this aim, the project bears four activities. These are: (1) diagnostics on the reading skills of SNHS students; (2) development and production of reading materials; (3) training of volunteer teachers and volunteer students; and (4) reading remediation camp.

The Year 1 implementation ushered-in the first batch of enrollees to the 15-day live-in summer reading camp at SNHS. To properly cater to the students' needs, the implementers opened the Project with a diagnosis of the reading skills of the Grade 7 students.

This activity would stir the Project to the correct direction. After a series of needs-analyses, the teachers identified around one hundred sixty students who fell into the frustration reading level. This would mean a greater number of learners who needed help. However, due to financial constraints, the implementers decided to limit the number to fifty. Therefore, another screening was conducted, narrowing the number to those in dire need in so far as reading. Of those shortlisted, only thirty four (34) student campers were able to finish the term.

On its Year 2 implementation, the project tracks the "frustration-level" readers who were subjected to the intervention the previous year. Further, it opened its doors to newcomers who were identified as "frustration-level" incoming Grade 8 readers. As the program has received recognition from other agencies, the Local Government of Asuncion has committed to help. This partnership resulted to increasing the slots to seventy (70) campers. Just like any other activities, the Project also adopted much-needed changes to better address the needs of the students and the teachers alike. One of the major modifications in the activities made was the transfer of Activity 2 "development and production of reading materials" to Project 2 (Mentoring the Mentors).

By the third year of implementation, seventythree (73) campers, twenty-one (21) volunteer teachers and twenty-one (21) volunteer student teachers participated. As it has received recognition from the Department of Education (DepEd) and other agencies, the implementers endeavored to abide by its design.

Propelled by its aim to transform readers who are on "frustration-level" to "instructional-level" readers, the Project is also determined to make the lives of these identified students better. This is made possible by giving them the chance to learn how to read and enjoy as they learn how to read. This is evident as the activities in the daily and nightly sessions involved social and psychological enrichment, above the cognitive ones. More importantly, it touches on the consequences of not being able to read as a grade-level reader.

\subsection{The theory: The Project's Anchorage}

The designers of the Project anchored SBB/S: LEARNING IS FUN on the Theory of Matthew Effects developed by Stanovich (1986). This theory refers to the idea that, in reading (as in other areas of life), the rich get richer and the poor get poorer. Hempenstall (2015) also cited that Stanovich used this theory to describe how, in reading, those who start well tend to continue to do so, while those who do not are unlikely to catch up. Not only do they not catch up. Accordingly, there will also be a widening gap between the slow starters and fast starters as their school career continues. He continued on that: There is ample evidence that students who do not make good initial progress in 
learning to read find it increasingly difficult to ever master the process.

A presentation in Wikipedia.org (2018) summarizes the theory as Stanovich applied it to education. This was used to describe a phenomenon observed in studies on how young readers develop the reading skills, that is, early success in acquiring reading skills. This, therefore, generally leads to later reading achievements as the learner progresses, although failing to learn to read before the third or fourth year of schooling may be indicative of lifelong learning difficulties. The reason is that children who fall behind in reading would read less, increasing the gap between them and their peers. Later, when students need to "read to learn" (where before they were learning to read), their reading difficulty creates difficulty in most other subjects. In this way, they fall further and further behind in school, dropping out at a much higher rate than their peers do.

When children fail at early reading and writing, they begin to dislike reading. They read less than their classmates who are stronger readers. When children with disabilities do not receive adequate remediation, they read less - and learn less from reading - than non-disabled children learn. Therefore, they do not gain vocabulary, background knowledge, and information about how reading material is structured (Wright and Wright, 2018).

This simply means that reading does not only affect the academic performance of the learners. It actually extends to other aspects of life that entail consequences in behavior and motivation of the students. This is very evident among the identified Grade 7 "frustration-level" readers of Sagayen National High School.

In order to address the reading needs of these students, it would also entail addressing the other needs linked to their failure to read. Thus, it aims to: 1) Assess the reading skills of the Grade 7 students in Word Recognition, Comprehension, and Reading Speed; 2) Train volunteer teachers and students in managing the activities in the reading camp; and 3) Conduct a fifteen-day live-in reading remediation camp.

Specifically, this study seeks to answer the following:

1. How were the students' behavior towards reading before the implementation of the project?

2. How were the students' behavior towards reading after the implementation of the project?

3. What important lessons were learned after the implementation of the project?

\section{Methodology}

\subsection{The Research Design}

The study employs the Participatory Action Research (PAR), as it involves its stakeholders in all endeavors. In this qualitative research methodology, the research generated ideas from the stakeholders who work collaboratively to address problems that occur in the locality. PAR, according to Kemmis and McTaggart (2000) is designed for people who plan a change, act and observe the process and consequence of change, and reflect on the actions and the consequences and then plan, act and observe, and reflect again (for enhancements).

Jacobs (2016) cites Reason and Bradbury describing that participatory action research combines theory and practice, action and reflection with the participation of stakeholders who seek practical solutions to concerns and issues, allowing the flourishing of those stakeholders and their communities as a result of the research process.

This is exactly what the project intends to advocate. In the context of the study, these stakeholders involve both government and nongovernment agencies who have been tapped to implement the activities. These include the University of Southeastern Philippines (USeP) through the Bachelor of Secondary Education Department (BSED) of the College of Teacher Education and Technology (CTET) Sagayen National High School (SNHS) as the partner beneficiary, Department of Education (DepEd), Commission of Higher Education (CHED), Local Government Units (LGU) of Asuncion and Brgy. Sagayen and private sponsors, among others. This team of stakeholders have conceived a change: to make the identified struggling/frustration-level reader become grade-level readers, at least.

\subsection{Data Dathering Techniques and} Participant

The implementation of the project opens the phase of acting and observing the planned activities. Data were collected in three ways: Indepth interviews, key-informant interviews and focus-group discussion among the participants. The researcher gathered the experiences and insights from the participants (teachers/implementers and students as beneficiaries). The responses were audio-recorded and then transcribed. After which, coding and assigning of themes were conducted.

As PAR is transformative rather than simply informative, according to Baldwin (2012), as cited by Jacobs, the observations were made as inputs from where the team based their reflections for the 
enhancements of the project. Therefore, the Summer Big Brother/Sister: Learning is Fun Project draws inspiration from the lived experiences of the participants. These experiences were then made as points of learning and later, enhancement. This part of the study constitutes the reflecting phase of the project.

\section{Discussion}

\subsection{The Intervention}

As envisioned, the project is set to transform learners to be more capable in reading and then in life. Johnston (2010) advocated that children who are disadvantaged at reading could develop consequences that are more serious. This means that what might appear to be a simple academic problem might progress into social struggles, when accumulated through the years. Thus, it is important to address this problem.

In order to stay on track, the implementers ensure that it does adhere to the principles of teaching and learning. Before the so-called treatment happens, a diagnosis is a significant element. The Project commenced its activities through Activity 1-Diagnostics of Reading Skills of the Students. This consists of the pretest that was focused on three reading skills, namely: word recognition, reading comprehension and reading speed. In the conduct of the diagnosis, the teachers made use of the modified instrument based on the Philippine Informal Reading Inventory (Phil-IRI). In the Year 1 implementation, about one hundred sixty nine (169) students fell on the nonreaders and frustration-level category. Due to constraints on resources, the implementers decided that fifty (50) students who needed the intervention the most $\mathrm{w}$ prioritized in the remediation camp, with the

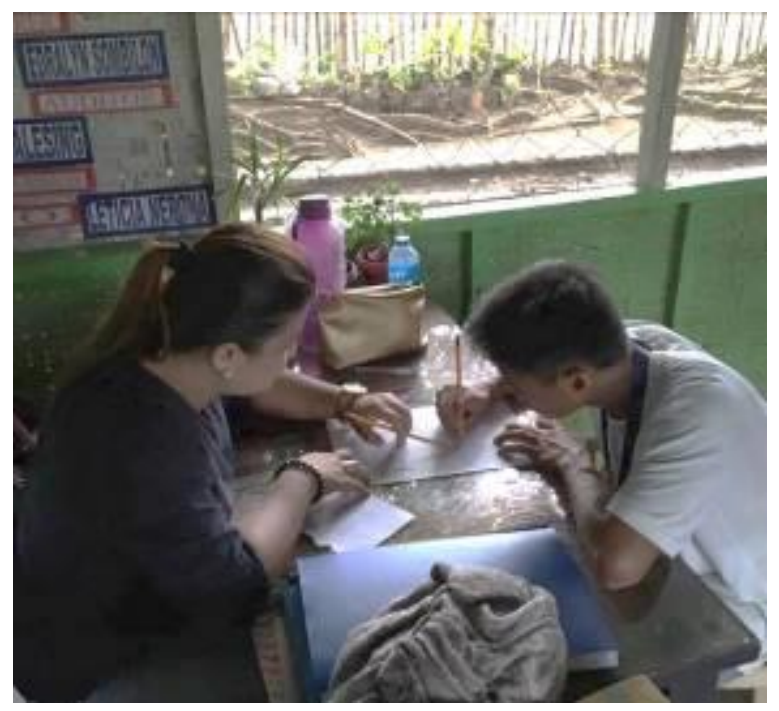

consent of the parents. In the actual camp, however, only 33 were able to join, as the rest were unable to do so, due to varied reasons. In the Year 2 implementation, the LGU-Asuncion committed to provide funds for the meals and requested that the number be raised to seventy students who were identified through the same procedure. However, during the orientation to the parents, about four students who belong to frustration-level readers were volunteered by their parents to be enrolled in the intervention classes. To this, the committee composed of the Program Leader, Project Leader and the SNHS Facilitators responded positively. This resulted to having 73 campers for the Year II camp. These were initially classified into three groups, namely: Beginning, Intermediate and Advance. However, during the third day of the session, the facilitators found out that the newcomers who are in the Beginning group still have to be classified further into Beginning Level 1, 2,3 , and 4 based on the severity of their reading performance. Those who belong to Batch 1 (Year 1) campers were classified either Intermediate or Advanced. Following the success of the implementation on the first two years, the third assessment catered to seventy-three student beneficiaries. By the 2019 implementation, the seventy-three students re-enter as student-campers. The same method of assessment was used in classifying them. As the Project bore the same commitment, the learners were assessed on the same reading skills. This was done so in order to keep track of their progress on word recognition, reading comprehension and reading speed. With this, the implementers could trace how the journey of each learner progressed.

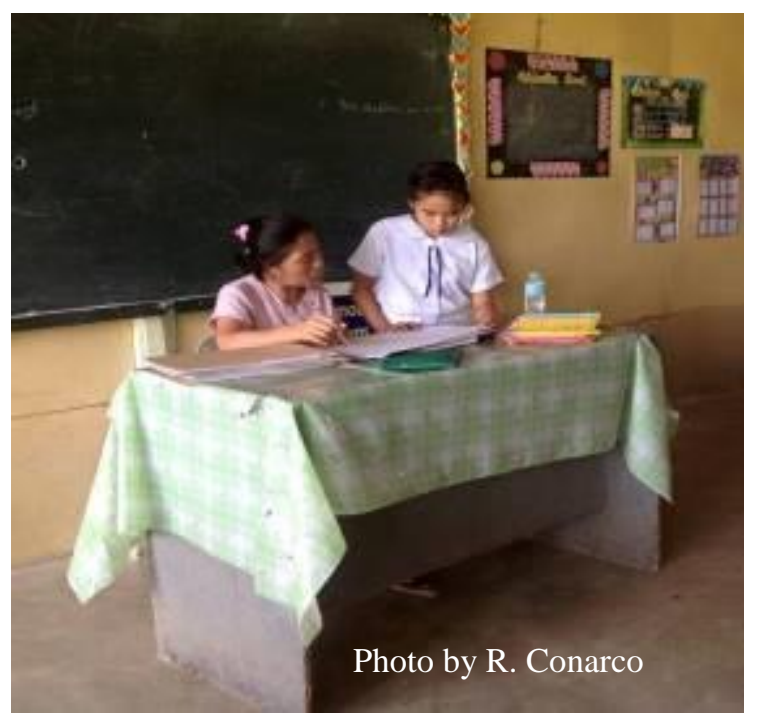


Before the conclusion of the reading camp of each year, the students were subjected to exit assessment. This assessment also involved the tracking of their performance in the same aforementioned skills. The post reading camp assessment showed a notable positive result. The students' performance have notably improved.

As mentioned earlier, the Activity 2, which was on Development and Production of Instructional Materials was initially designed to be in Project 2. It specifically targeted the formulation of reading materials that would answer the needs of the students who undergo the reading remediation camp. The materials developed were focused on developing the skills the students would require in order to become better readers in terms of word recognition, reading comprehension and reading speed. The volunteer teachers initially designed the materials and then presented them to identified experts on reading for review. It is noteworthy to mention that there were materials that were not used in the actual conduct. This was because necessary adjustments were made in order to better suit the needs of the students.

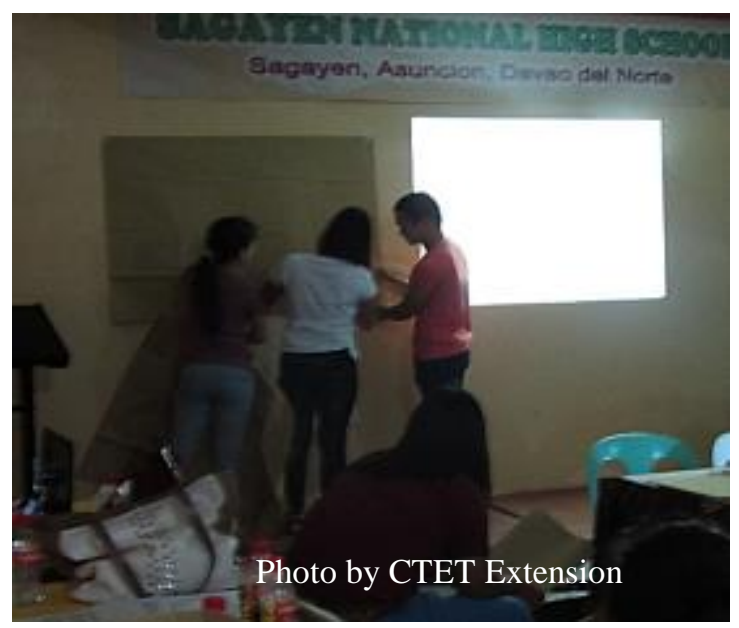

SNHS teachers and USeP BSED-English PSTs were tapped to "man" the camp. Because they are the ones who are directly involved in the conduct of the remediation activities, it was deemed necessary to orient them with the activities that are conducted in the camp.

Post-activity evaluation revealed that it would be better to transfer this activity to Project 2 (Mentoring the Mentors) as this capacity building is intended for the teachers. Therefore, this activity was no longer a part of Project 3 in the Year 2 and Year 3 implementation.

For the Year 1 (2017) implementation, the second activity in the project was the "Training for Volunteer Teachers and Students". The said participants were oriented on the tasks and responsibilities that were expected of them, along with the activities designed to be conducted on daily and nightly bases. This was also the time for the teachers who would be the session managers and the USeP PSTs who were to be the assistant session managers, to meet. During the meets, the session managers gradually modified the materials, as they eventually got to know the learners assigned to them via the learners' profiles. Because of the previously mentioned modification, this activity became Activity 2 in the Year 2 (2018) and 3 (2019) implementation.

The Reading Remediation Camp concluded the previous activities in the Project. This was a fifteenday-live-in reading camp inspired by the Summer Big Brother program of the Province of Compostela Valley. The activity made use of the pre-designed activities crafted by the teachers and studentteachers with consultation from experts. These instructional activities were programed by session. The events in the camp, specially designed to maximize the stay of the students, were set on daily basis and even utilizing the evening sessions. It included physical, social, emotional and intellectual development. The sessions were manned by the identified SNHS teachers, USeP BSED English PSTs. Identified CTET faculty members would also spend the nights on-site. Year 2 implementation saw a milestone of the Project. It was found out on the third day of the camp that the Beginning Group was composed of students with varied sub-groups. The purpose would have been futile if this group was not further divided. And so, the Beginning Group was regrouped into Level 1, 2, $3 \& 4$ where Level 1 had 15 campers; 15 for Level 2; 8 for Level 3; and 10 for Level 4. This was made possible because of the result of the further assessment, supported by observations of the session managers. With the sub-grouping, the remediation efforts were made more specific and individualized. 


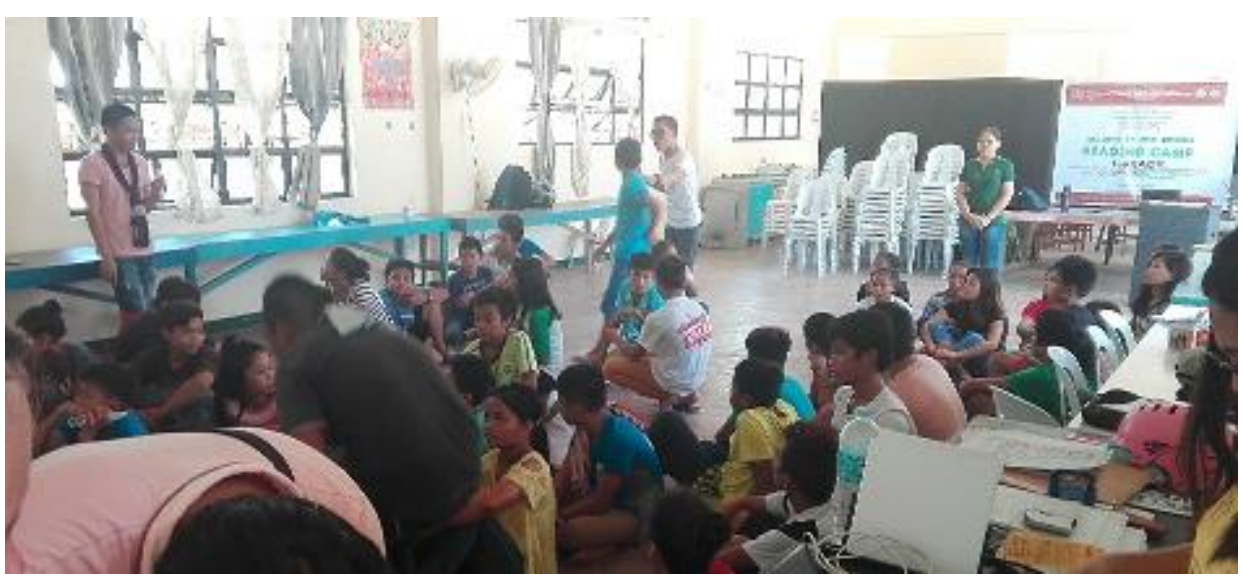

The camp's activities included storytelling, games, activities, group/small group dynamics and other hands-on and one-on-one activities. The days would start with a brief spiritual preparation through the daily prayers led by the campers. This would then be followed by the early morning physical exercises. A brief break is then given for the campers for personal preparations and then for breakfast. Campers would then get on with their hygiene-related activities and then proceed to their assigned classrooms for the day's reading activities. The day's events would conclude with the evening psychological and socialization activities.

In this activity, parents of the studentbeneficiaries were also involved as they were the ones who took care of the cooking and serving of the meals. Some parents even provided provisions as addition to the preparations made by the implementers along with some sponsors. The parents were witnesses to the transformation of their children as they were around the whole time.

This activity ended with a culmination on its fifteenth day, when the student campers would display their reading skills through various reading activities.

As a project, the Summer Big Brother/Sister synthesizes the major undertakings of the whole extension program. This is so, as the ultimate aim is to improve the reading performance of the frustration-level readers. It should be noted, however, that the capacity building of the teachers in Mentoring the Mentors Project is instrumental in the success of the reading camp and the I-READR Program in general.
With transformation as its ultimate end, the project has contributed to the development of the readers, not only on their reading but also on a deeper sense - their psyche. This is what the Project envisions to achieve.

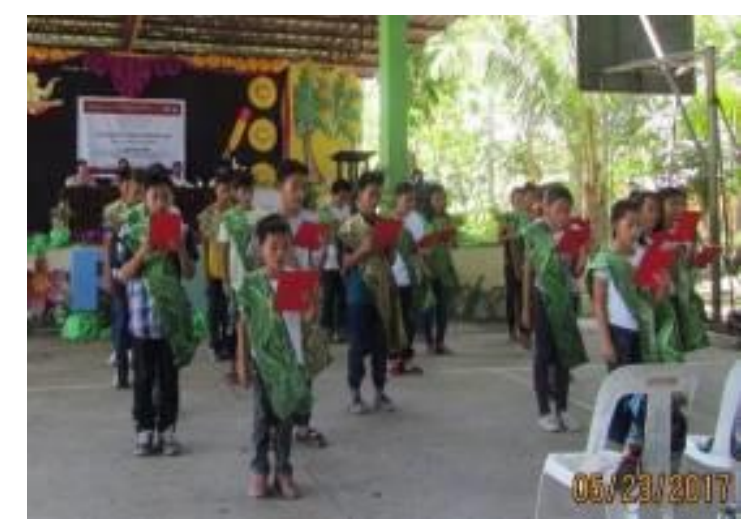

3.2 What lies beneath: Behavior before the project

People tend to be frightened by the prospect of change. However, these student-campers of Sagayen National High School braved the challenges upon them. Before the implementation of the Project, these students have different reasons for not being able to read, for not reading, and for not attending their reading classes.

Motivation is a key factor in literacy learning and struggling readers may process differently than on-level readers (Compton-Lilly, 2008 as cited by Wilson, 2012).

When asked to describe her students before the camp, one teacher recounted:

"Before the camp, the pacing of their reading was slow. They were hesitant to participate in class activities. I have to exert more efforts to encourage them to get involved in class activities. Most often, the meetings would involve reprimanding my 
students and lecturing them on the significance of reading. To this, they seemed to respond positively for the moment. However, it was back on square one the next day."

Another teacher shared that her students used to have no self-confidence. Still others even resorted to absenteeism so that they would not be called upon to participate to activities especially reading. She further narrated that one of her students "would make many excuses once called to participate".

"One of my students would always say 'no' when asked to read something. This annoys his other teachers."

The students themselves corroborate these observations/remarks of the teachers. When asked how they were before the camp, their usual answers were:

“Dili ganahan mu-adtu ug school kay magbasa."

("I do not like going to school because I would be made to read.")

“Dili ku mutingug kung mangutana si Ma'am sa klase kay maulaw ku bisa'g usahay kabalu ko sa answer kay basi'g pabasahun ku."

(I do not answer my teacher's questions even if sometimes I know the answer because I might be asked to read.”)

"Ma-ulaw ku makig-uban sa akung mga classmate kay kama-u man sila mubasa, aku kay dili man."

(I am ashamed to be with my classmates because they know how to read and I don't.")

It is evident in the responses presented here that the inability to read of the students has affected their other activities. For example, one prefers not to interact with their classmates because they can read. This inability to read has made the student aloof (as one teacher commented).

This observation is supported by The Reading Foundation (2019) presenting that academic, emotional and social issues abound for children who are poor readers. Children who are behind their peers in reading struggle with low self-esteem and feelings of inadequacy. Low achievement in reading is also the common denominator in school discipline, attendance and dropout problems, and juvenile crime.
This was evidently observed among the students. Because they do not know how to read, they prefer to keep it to themselves, afraid for the others to find out about it.

This so-called isolation may not be good to the students at all times. For one, it is an established fact that human beings are social beings. As Aristotle advocated, "man is a social animal". Thus, students need to socialize with other students, their teachers, and other members of the community.

As emphasized in the Matthew Effects theory, the "disadvantaged child in terms of reading becomes even more disadvantaged". This is because his difficulty to read renders him to "isolate" himself. Thus, resulting to "consequences in behavior and motivation" of the students.

Still others resorted to more serious behavior bullying. Because they could not read, they put on their masks by acting as bullies. This resulted to another problem to the teachers. According to them, their students became aggressive when reading matters were brought up. With the teachers' initiatives, they found out that it was their inability to read that was the root of the problematic behavior.

The above findings conform to Shepherd's (2017) reference to Johnson and Winogard (1985) specifying that these nonreaders' feeling of helplessness and hopelessness may make them vulnerable to anti-social behavior. With this, students with very weak reading skills have serious academic problems, which can develop into social problems as they reach the middle and high school years. Through years of failure and labeling, they often develop hard shells of resistance to reading. They compensate with strong auditory and observational skills, generally trying to avoid notice. Feeling helpless and hopeless, they may be vulnerable to anti-social behavior.

With these responses from the students, Abrams, a well-respected psychologist who specialized in reading disorders, as cited by Margolis (2019) said it is almost inevitable that a child who is experiencing severe difficulty in reading will develop intense feelings of frustration. As reading failure continues, many symptoms of social and emotional maladjustment will appear. 
This explains the bullying acts of these struggling readers. To this, Margolis added that children's inability to read puts them in a compromising situation. They "cannot risk another humiliation" so all too often, they act out aggressively, withdraw, become depressed or choose any one of many other maladaptive solutions."

Jennings, Caldwell and Lerner (2014) also pronounced that: for the poor reader, school experiences are often unhappy ones. Also, students with reading problems often have unsatisfactory relationships with adults in the schools. Studies show that poor achievers tend to be perceived negatively by teachers, paraprofessionals, and principals. Teachers often identify poor readers as aggressive, lacking self-discipline, and unmotivated. Low achievers receive less praise or acknowledgment from teachers, and they are more likely to be criticized.

Morgan, Farkas and Wu (2015), in their study, Do Poor Readers Feel Angry, Sad, and Unpopular? claim that the results indicate that those children who are poor readers or who are poorly skilled in mathematics are also at increased risk of socioemotional maladjustment. However, poor reading ability may contribute to more generalized socioemotional maladjustment, while poor mathematics ability may contribute more specifically to internalizing psychopathology

Like an iceberg, there is a much bigger mass of ice underneath it. This mass is what is keeping it solid. What is visible may not be the bigger problem; instead, it is what is hidden from view, more serious, something invisible.

\subsection{Marching Forward: Behavior after the} project

The Project enabled the campers to work on individual and group activities. They were given sessions that would require them to discuss solutions and alternatives to presented problems. Daily activities gave them simple tasks and responsibilities in the upkeep of their quarters. During evenings, they play games and watch educational movies together. Apart from the individual activities in the camp, they were also given tasks that would require cooperation among their co-campers. This, according to the teachers had been instrumental in the development of the students in terms of socialization. The once-aloof children have started coming to terms with their peers. They have developed "buddies" among them, who have become their companions in the camp.

When asked of their observations after the students have joined the reading camp, the teachers reported that they have observed changes in the students/ For one, the opened up to participate in class. This is evidenced by the response of one teacher who said:

"There is improvement in his reading speed. He already participates in class activities."

Another commented, "Some of my students who were in the camp last summer have started to participate in the class. I can see that they have developed confidence." This is another manifestation that the improvement in their reading has also made them gain self-confidence.

Other comments can be summarized as:

"There are a lot of improvements because after the reading remediation camp last summer, I was able to handle the former 'aloof', silent and noncooperative students.

"Now, my co-teachers say that they have noticed the improvements that our students got from the camp. Instead of enumerating excuses, my students who attended the reading camp already volunteer to read in the class."

One teacher even commented:

"When I would ask them to read a paragraph from the book, Arthur (not his real name), was able to read it clearly and loudly."

Student-campers have also been observed to have "circle of friends" already. This is shown as they go around the school with their peers.

"I have seen students, who used to sulk by themselves, now eating lunch and snacks with their classmates."

"It appears that they have kept the friendship that they have gained in the camp."

The observed changes in the behavior of the students may be attributed to their triumph by participating in the efforts to "make them better readers". Indeed, success is sweeter when one is involved in the efforts.

\section{The realities now: lessons learned}

It is noteworthy to mention what the teachers have to say when the teachers were asked what they 
have learned during and after the camp. Some of them answered:

"It is true that once the child knows how to read, other skills would follow."

"I have seen that many of the excuses of my students stemmed from their inability to read. Their misbehavior in class was, in reality, prompted by this problem.

"The root cause of their misbehavior in the class including absenteeism and bullying, was that they could not read. There is no more bullying because they are already buddies."

"I have seen how my students transformed into persons who play their part in school and in the community."

As the Matthew effect theory suggests, early detection of the difficulty means early intervention. This entails giving the children the chance to overcome the difficulties. As they progress from their difficulties, they become individuals who are more responsible. Therefore, overcoming more than the challenges of a "frustration-level" reader. With this, teachers also become more involved in the lives of their students.

Another important effect that the Project has brought is the involvement of the parents in their children's academic life. As Teacher C stated:

"When I talked to some of the parents of the campers, I realized that they have become involved because of the Project. Although they are busy with earning a living for the family, their participation has made them see the important role they play in the lives of their children."

Teacher D also shared what he has observed in the behavior of the parents:

"The parents of these children are usually not participative to school activities. However, after they got involved in the camp, they opened up to discussions about the status of their children's education."

Both the parents and the students, along with the teachers and implementers, have been transformed one way or another. Truly, the Project has also succeeded in involving the parents in order to engage them and take their part in the journey of their children.

Margolis (2019) claims that generally, those with greater social and emotional understanding and skills do far better in every major aspect of life than those who struggle. Compared to those who struggle, they are happier, healthier, and more productive. Usually, they enjoy and keep their friends and tend to avoid the life-threatening dangers of loneliness.

In her study, The Reading Experience: How Struggling and Non-struggling Readers Differ, Garret (2012), cited Triplett's (2004) examination of the difference of emotions between a student in a classroom setting and in a tutoring setting. The student was described by the teacher as a struggling reader who often had emotional breakdowns during instruction. However, during tutoring sessions, there were no signs of negative emotions elicited. By allowing the child to participate in his own academic success, he went from a struggling, emotional reader to a positive and capable reader.

Indeed, challenges and stumbling blocks along the way did not make the Project less of what it was designed to be. It has made an indelible mark on the lives of not just the students, but also the parents, teachers, the volunteers and the implementers.

It is not surprising at all that stories from the participants who have competed the camp consist of positive effects of the Project on the behavior of the students. This is an unintended yet a very-much welcomed outcome, in addition to the improvement in reading skills.

When the learners learn how to read, they also learn a very important skill. The Summer Big Brother/Sister: Learning is fun Project has transformed the struggling readers to get through that invisible word. That is, gaining self-confidence to engage in reading and the many more beautiful things that reading can give. When they have conquered this invisible word, then they are ready for the challenges the world has to offer.

This is just a crack in the tip of the iceberg, and much is still needed to be done. What is important, however, is that something has already been done.

\section{Conclusion}

\subsection{Implementation}

From the meager thirty-four (34) students on the first year of implementation, the Project has involved seventy-three (73) student-campers, twenty-one (21) SNHS teachers and twenty-one (22) student-volunteers in its three activities on 
both second and third year. This is on top of the other stakeholders, such as: USeP personnel, LGU personnel including the security personnel, and parents.

The Project envisions to transform what Franz (n.d.) describes to be the frustration-level reader as somebody who is obviously struggling to read and has numerous errors. In so doing, it also transforms the affective state of the learners, making them more involved socially. This has been made possible through the achievement of the Project objectives: to diagnose the students in their reading skills, conduct training for the volunteer teachers and students, and conduct the 15-day reading remediation camp.

\subsection{Issues and Challenges}

\subsubsection{Project Management}

The project was made possible through the combined efforts of USeP and SNHS administration and faculty. However, due to the "overloading" of work and responsibilities of the committee members, there were aspects of the project that have been missed.

\subsubsection{Partnership}

Some partners were not able to perform as expected of them. To cite an example, the Barangay LGU of Brgy. Sagayen was expected to extend assistance in securing the participants and the teachers but there were times when there were no tanod members who stay in the premises to secure the area. Also, the municipal mayor had promised that the PNP personnel of Asuncion were to provide security but showed up on occasions because they were busy preparing for the election accordingly. Also, some of the specifications in the design of the Camp especially in the preparation of healthy and nutritious meals were not followed. Instead, the meals prepared were of minimal budget, without taking into consideration the fact that the students needed to be nourished physically in order to meet the cognitive and psychological challenges.

\subsubsection{Timing}

Due to the bulk of work of the SNHS teachers, the assessment was not done in one setting. This was staggered/distributed during the vacant time of the students and the teachers. Some sessions in the Remediation Camp were lumped because the campers and the teachers had to be sent back home because of the local (barangay and SK elections). This was done to ensure the security of the participants and the teachers on the day.

\subsubsection{Relevance of the activity}

The project in its totality is relevant as it has already become alarming that the reading level of the students in the secondary school is deteriorating. To cite an example, a number of incoming Grade 9 students do not even know how to identify/read the letters in the alphabet. Yet, they were promoted. Also, the love for reading should be instilled among these students as this has become one of the many causes why students these days no longer read according to the level expected of them.

\subsubsection{Sustainability of the Project}

The implementers of this Project have invested time, effort, money and many more for its realization. Throwing this down the drain would mean throwing away the accomplishments and the future differences that it could bring. This is not only for the students struggling with reading and socialization, parents' struggling to make a living for their family and guiding their children in their journey, but also to the country that is trying to solve problems that are brought about by the inability to read. It is therefore imperative to continue the Project.

\subsection{Behavior before the Intervention}

It was evident that what appeared to be the inability of the students to read the written word, has consequences that are more serious in the academic, social and emotional aspects of their lives. The results from the focus group discussions, in-depth interviews and key informant interviews have revealed that these students engage into bullying, isolate themselves from their peers, and refuse to participate or even attend classes, among other, because they do not know how to read.

\subsection{Behavior after the Intervention}

With the fifteen-day reading remediation camp, the students have become better readers who can already recognize words. More importantly, along with the better performance at reading, they have become more open to their peers and have established friendship among them. Most teachers have also observe that these students, who used to 
avoid them, would already meet to greet their teachers both inside and outside school premises. They have also been observed to participate in the class activities and since they already have friends, they no longer bully other students.

\subsection{Lessons learned}

As the Matthew Effects theory suggests, early detection/ recognition of reading problems means early intervention. Thus, avoiding the downward spiral of achievement in which initial lack of success in reading can develop into widespread language and cognitive deficits (Ceci, 1991 cited by Hempenstall, 2015). With the intervention in reading, the students have become better readers and have developed confidence to go out and socialize with their peers and teachers.

\section{Recommendations}

Based on the data gathered from the activities of the project, the following recommendations are drawn:

1. Diagnosis should be made more rigid. Conduct of the pretest and posttest should be in accordance to the requisites of diagnosing reading skills and be done earlier to give time to the development of instructional materials;

2. Training for volunteer teachers and students should be made stricter and more engaging. This shall equip the teachers and volunteer PSTs on the management of the sessions in the camp;

3. Conduct of the reading camp should be made more participant-centered. With all the stakeholders playing its roles, other stakeholders should be rechecked in terms of their commitment.

4. More carefully-planned activities (that would engage the learners in the camp) should included. These should be made to cater not only to cognitive but also their affective selves. This should be made possible as it is more difficult to treat the affective aspect of the learners.

5. More psychological and socialization activities should be integrated in the Project.

6. This Project should be continued until all the "frustration-level" readers have graduated and become "instruction-level" readers who are confident and are emotionally stable.

\section{REFERENCES}

[1] Franz V. (2011). What Do Reading Levels Mean? Retrieved from http://www.thudcave.com/ lamplighter/index.ht m on December 2, 2018.

[2] Gafney, M. (2008). Participatory Action Research: An Overview What makes it tick? KAIRARANGA Volume 9.

[3] Garrett, J. (2012). The Reading Experience: How Struggling and Non-struggling Readers Differ. Retrieved from: https://fisherpub.sjfc.edu/education_ETD_masters.

[4] Hempenstall K. (2015). What are these Matthew Effects? Retrieved from https://www.nifdi.org/blog-hempenstall/399what-are-thesematthew-effects on December 4, 2018.

[5] Jennings, Caldwell \& Lerner (2014). Reading Problems: Assessment and Teaching Strategies Retrieved from https://www.pearsonhighered.com/assets.

[6] Lestrud, M. (2013). Reading Skills. In: Volkmar F.R. (eds) Encyclopedia of Autism Spectrum Disorders. Springer, New York, NY.

[7] Margolis, H. (2019). Struggling readers have no time to lose: Social-emotional learning. Retrieved from https://exclusive.multibriefs.com/content/struggling -readers-have-no-time-to-lose-social-emotionallearning/education

[8] Morgan, Farkas and Wu. (2015). Sci Stud Read.

[9] Shepherd, N. (2017). Helping non-readers grades 4-12. Retrieved from https://silo.tips on January 18, 2021.

[10] Stanovich, K. (1986). Matthew effects in reading: Some consequences of individual differences in the acquisition of literacy. Reading Research Quarterly, 22, 360-407. Retrieved from http://www.readingrockets.org/articles/researchbyto pic/4862 on December 4, 2018.

[11] Wright P. and Wright P. What is the Matthew Effect? Retrieved from www.wrightslaw.com/ info/test/mattew.effect.htm on December 6, 2018.

[12] The Reading Foundation. (2021). https://www.readingfoundation.org/the-impact

https://en.wikipedia.org/wiki/Matthew_effect 